\title{
Soil Preparation Studies: II. The Effect of Depth and Method of Soil Preparation and of Organic Material on the Performance of Vitis vinifera (var. Colombar) on Clovelly/Hutton Soil
}

\author{
D. SAAYMAN \\ Oenological and Viticultural Research Institute, Private Bag X5026, Stellenbosch, 7600.
}

\begin{abstract}
As a follow-up for similar investigations carried out in the irrigation area of the Breede River valley, the effect of different methods of soil preparation on the performance of Colombar/143B on a Hutton/Clovelly soil was studied at Stellenbosch in the Cape coastal area. Results were generally in accordance with those obtained in the Breede River valley studies, and showed no convincing effect of organic material additions but a strong positive effect of depth and efficiency of soil loosening. Root growth was related to the soil volume loosened and to vine performance. Roots tended to concentrate in the surface soil layers in shallow soil but showed a more desirable uniform distribution in delve ploughed soil. Although costly, delve ploughing the soils investigated in this study is clearly economically justifiable, primarily because the vineyard reached its potential production level sooner. The effect of eliminating excess acidity during soil preparation was not studied in this project, and no optimum soil volume could be determined because of the inability of the implements used to attain sufficient depths. These two aspects are regarded as very important and merit further study.
\end{abstract}

The importance of good physical soil conditions to ensure optimal conditions for root and plant growth, the considerations involved in creating the desired physical conditions, as well as the general situation concerning soil preparation practices in South Africa, have already been discussed, and the results of a soil preparation trial in the Breede River valley were reported (Saayman \& Van Huyssteen, 1980).

The traditional wine producing areas of the Coastal region in the vicinity of Cape Town, Stellenbosch and Paarl, are all characterised by commonly occurring soil types known as Hutton and Clovelly soils. Although these soils are usually preferred to other associated duplex soils for vineyard plantations, they present problems in being acid and noticeably dense in the subsoil layers in spite of being classified as having apedal (structureless but physically favourable) B horizon characteristics (MacVicar $e t$ al., 1977). It is general practice amongst wine farmers, therefore, to alleviate these problems by loosening the soil with powerful soil preparation implements and by adding organic material and/or lime. However, the question still remains whether such soil preparation practices, costing R700 to R900 per hectare, are economically justifiable. In this paper the results of an investigation of soil preparation treatments in the Stellenbosch area of the Cape coastal region are reported.

\section{MATERIALS AND METHODS}

Soil and Climate: The experimental vineyard was planted during 1967 on the OVRI experimental farm, Nietvoorbij, situated in the Cape coastal region. The soil concerned is a.highly weathered, yellow-brown to red apedal soil of medium to heavy texture, developed from Malmesbury shale and colluvial material of granitic origin. It has a bulk density of $1,5 \mathrm{~g} / \mathrm{cm}^{3}$ in the topsoil, increasing to $1,75 \mathrm{~g} / \mathrm{cm}^{3}$ at a depth of $90 \mathrm{~cm}$. The soil has a westerly aspect with a $10-15 \%$ slope, and is characterised by the presence of relic termite nests or so-called "kraaltjies" (Merryweather, 1965), which are typical in soil on higher, old landscape positions in the coastal area, and give rise to a very complex soil pattern which complicates experimental lay-outs considerably.

The climate of the area is typically mediterranean with a mean annual rainfall of $c .690 \mathrm{~mm}$, of which c. $30 \%$ occurs during the growing season (September to March). The heat summation is 1946 degree days, placing this region exactly midway between Regions III and IV as defined by Winkler et al., (1974).

Experimental design: Colombar vines grafted onto 143B rootstock were used as test plants. The planting density was 2157 vines/ha $(3,05 \times 1,52 \mathrm{~m})$, the vines being developed with four permanent cordons (H-development) on a gable trellising system (Zeeman, 1978), and pruned to approximately twenty two-bud spurs per vine. Because part of the soil had already been ploughed to a depth of $76 \mathrm{~cm}$ before the start of the trial, it was divided into two experiments viz:

Experiment I: A randomised block design consisting of six organic material $(\mathrm{OM})$ addition treatments, replicated six times, with each block sub-divided into two ploughing depth sub-treatments of $76 \mathrm{~cm}$ and $122 \mathrm{~cm}$, respectively. The OM was placed in the open furrow created by each traverse of the delve plough, and these treatments consisted of:

Ia: No organic material

Ib: 660 bales of straw/ha $(c .10,7 \mathrm{t}$ straw/ha)

Ic: 1025 bales of straw/ha $(c .16,6 \mathrm{t}$ straw/ha)

Id: $34 \mathrm{~m}^{3}$ compost $(c .12 \mathrm{t}$ compost/ha)

Ie: $50 \mathrm{~m}^{3}$ compost $(c .18 \mathrm{t} \cdot \text { compost } / \mathrm{ha})^{2}$

If: 660 bales of straw $+34 \mathrm{~m}^{3}$ compost/ha (c. $23 \mathrm{t}$ $\mathrm{OM} / \mathrm{ha})$

In all relevant treatments fresh wheat straw and municipal compost were used. Sub-treatment plot size was $279 \mathrm{~m}^{2}$, each consisting of 21 experimental vines, flanked by two border rows and vines on each side.

Experiment II: A randomised block lay-out consisting of six replicates and five ploughing depth/OM combination treatments, viz:

IIA: Shallow delve plough $(30 \mathrm{~cm})$, no OM

IIB: Subsoiler $(90 \mathrm{~cm})$, no OM

IIC: Delve plough $(107 \mathrm{~cm})$, no OM

IID: Delve plough $(107 \mathrm{~cm})+1540$ bales of straw/ha (c. $25 \mathrm{t}$ )

IIE: Delve plough $(107 \mathrm{~cm}), 66 \mathrm{~m}^{3}$ compost/ha $(c .23 \mathrm{t})$

Plot size was $873 \mathrm{~m}^{2}$, each containing 46 experimental 


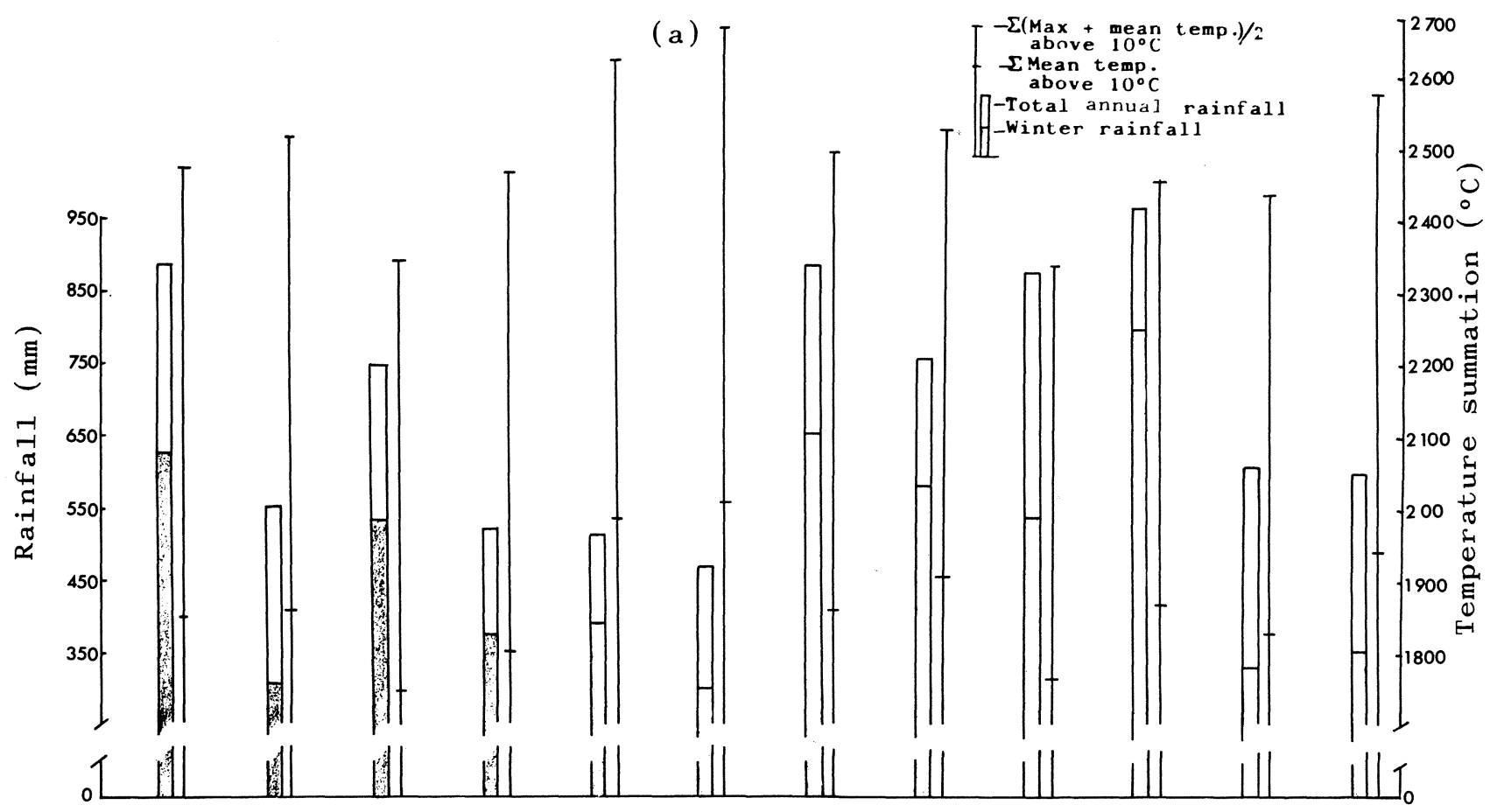

(b)

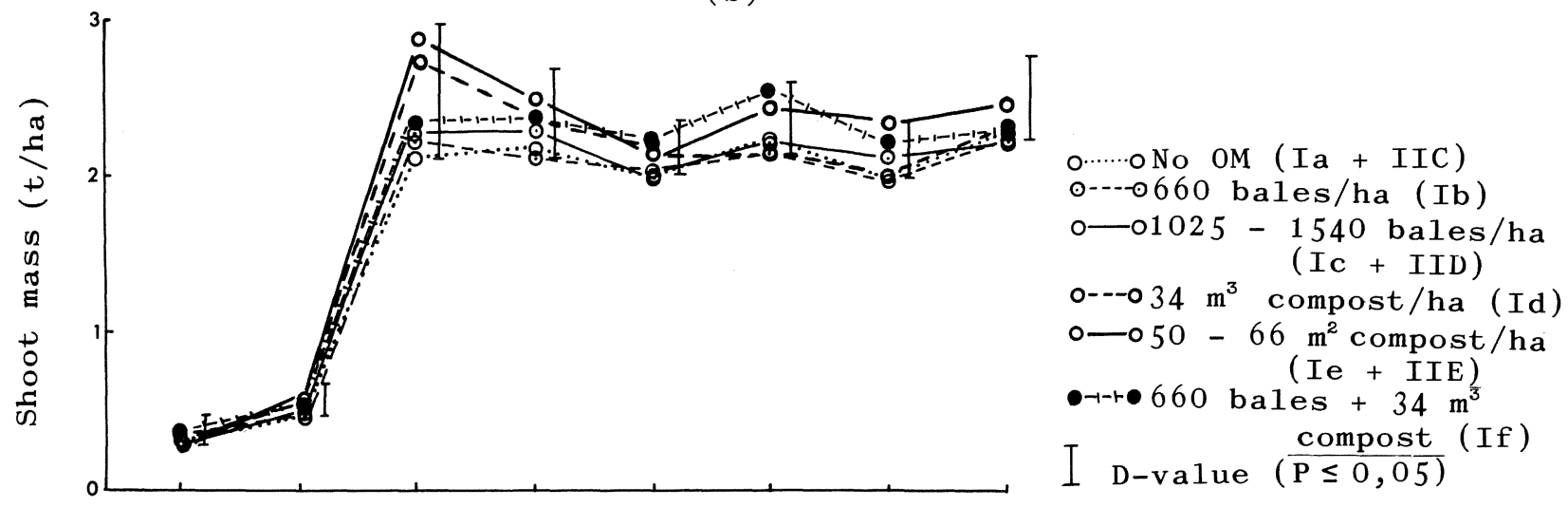

(c)

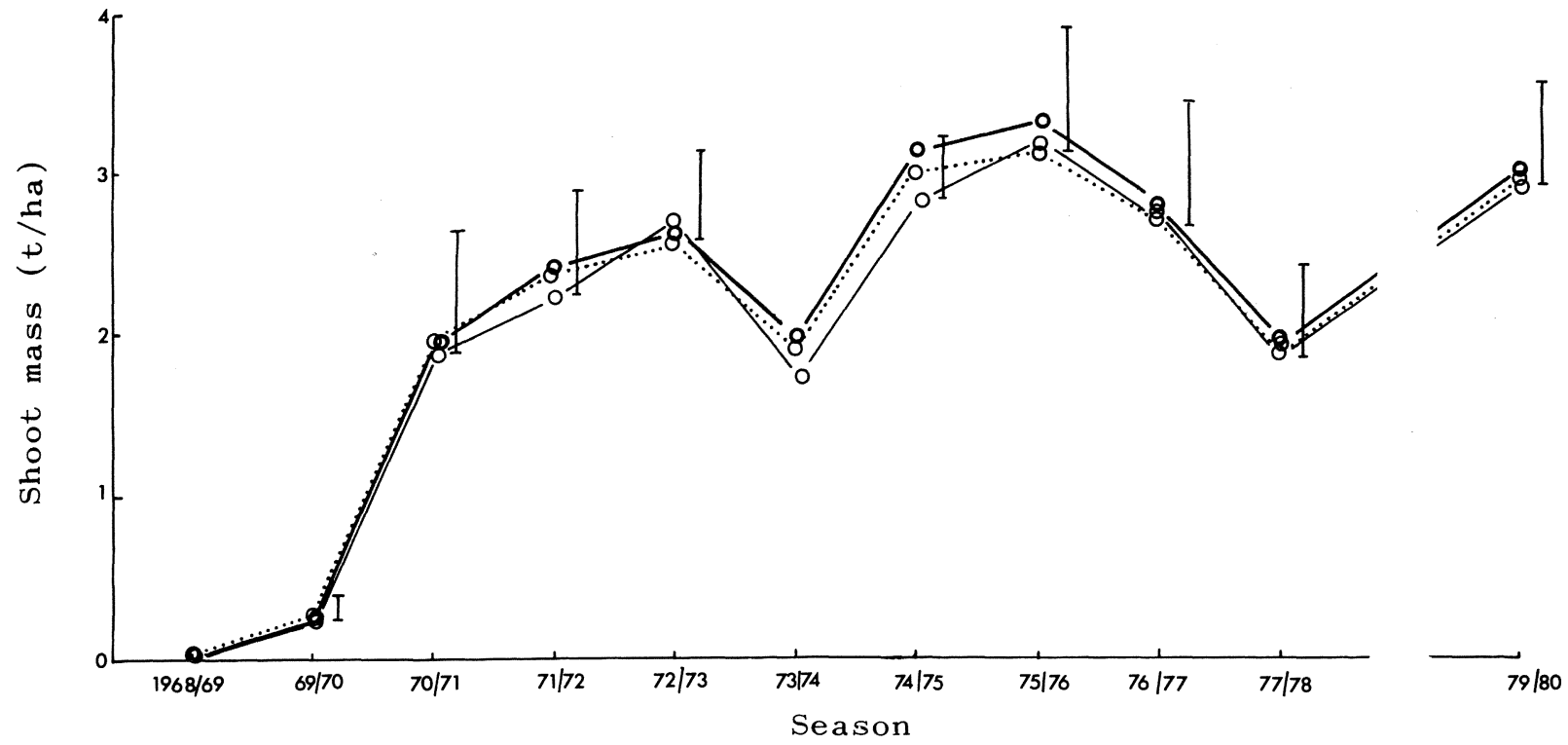

Fig. 1

The effect of organic material on shoot mass of Colombar/143 B, Stellenbosch (b) Experiment I; (c) Experiment II in relation to corresponding temperature and rainfall (a) 
vines, flanked by two border rows and vines on each side.

Soil preparation treatments and cultural practices: A drawbar type, single share plough and a $175 \mathrm{~kW}$ crawler tractor were used for the delve plough treatments, whereas the same tractor coupled to a drawbar type, single tine subsoiler (ripper), was used for the ripper treatments.

Superphosphate $(2 t / h a)$ was applied to all treatments during the deep ploughing operations, and the vineyard was clean cultivated in combination with the traditional practice of making trench furrows between alternate rows in which prunings are placed and ploughed under. Since 1976, chemical weed control was practised on the entire soil surface. Irrigation was applied according to calculations of evaportranspirative demand, usually amounting to $50 \mathrm{~mm}$ during December and another $50 \mathrm{~mm}$ during January.

Measurements: Shoot and crop mass, total titratable acidity (TTA), total soluble solids (TSS) and $\mathrm{pH}$ of the must were measured each year, using only vines that conformed to minimum standards, i.e. two permanent cordons already developed on the vine, and expressing shoot and crop mass on a per hectar basis. Thus the number of vines measured per plot increased during the initial years. A soil survey was carried out and studies on root distribution were conducted during 1980 by digging profile pits at right angles across the experimental rows of Experiment II treatments. The profile wall studied was situated midway between two adjacent vines in a row and continued for a distance of $1,5 \mathrm{~m}$ to each side of the row, thus representing one side of the theoretical rectangular soil volume occupied by the roots of each vine. The vine selected had a shoot mass equal to the mean shoot mass per vine of each plot. The loosening effect of the soil preparation treatment was visible and could be verified by means of a geological pick on the relevant profile pit wall. The lower boundary of loosened soil was plotted on graph paper, together with the presence of roots exposed over a depth of $5 \mathrm{~cm}$. Roots were classified, using three thickness categories viz: $<2 \mathrm{~mm} ; 2-7 \mathrm{~mm}$ and $>7 \mathrm{~mm}$ diameter.

During 1973, irrigation water run-off was measured in Experiment II by building dams which encompassed the $4 \mathrm{~m}$ diameter wetting zone of a single sprayer and by collecting and measuring run-off water at $10 \mathrm{~min}$. intervals.

Representative soil samples of the different soils involved were taken for chemicai and mechanical analyses. Leaves adjacent to bunches were sampled during December 1980 from all vines in Experiment II subjected to root studies, and were separated into blades and petioles before analysis. Standard OVRI analyses procedures were used throughout for both soil and leaf samples.

\section{RESULTS AND DISCUSSION}

Shoot Growth and Yield: As shown in Fig. 1, organic material (OM) additions had no statistically significant effect on shoot mass. The pronounced decrease in shoot mass per hectare in Experiment II during the 1973/74 season (Fig. 1) was caused by the hot and dry 1972/73 and 1973/74 seasons. The fact that this dip was not experienced in Experiment I was due to an increase in the

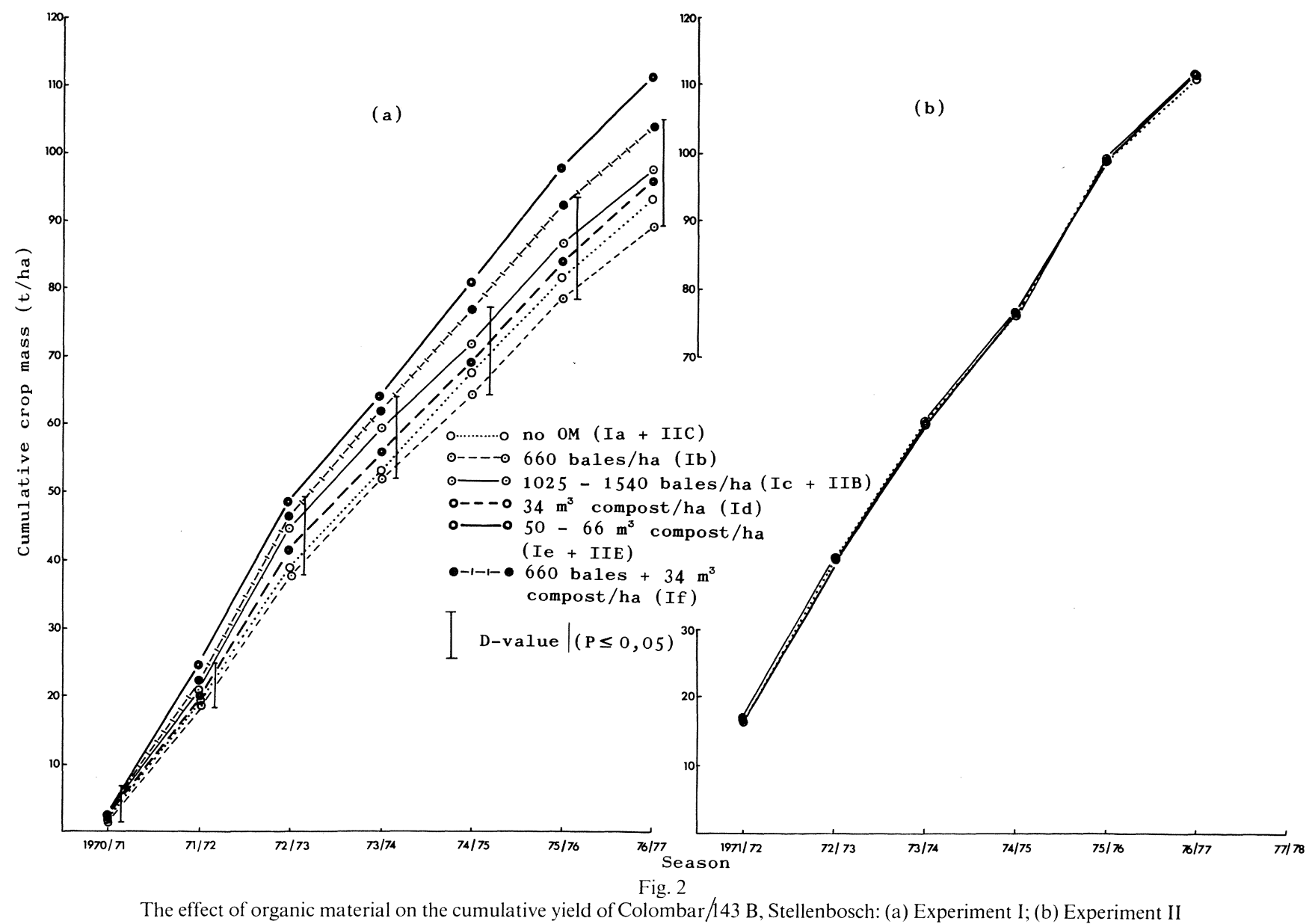

S. Afr. J. Enol. Vitic., Vol. 3. No. 2. 1982 
TABLE I

Chemical and mechanical properties of soils identified in Experiment I and II, Stellenbosch

\begin{tabular}{|c|c|c|c|c|c|c|c|c|c|c|c|c|c|c|c|c|c|c|c|c|}
\hline \multirow{2}{*}{ Location } & \multirow{2}{*}{$\begin{array}{l}\text { Soil }{ }^{* 1} \text { type } \\
\text { (Profile No) }\end{array}$} & \multirow{2}{*}{ Horison } & \multirow{2}{*}{$\begin{array}{l}\text { Depth } \\
(\mathrm{cm})\end{array}$} & \multirow{2}{*}{$\begin{array}{l}\mathrm{pH} \\
(\mathrm{KCl})\end{array}$} & \multirow{2}{*}{$\begin{array}{l}\mathrm{P} * 2 \\
(\mathrm{ppm})\end{array}$} & \multirow{2}{*}{$\begin{array}{l}\mathrm{C} \\
(\%)\end{array}$} & \multicolumn{5}{|c|}{ Extractable cations $(\mathrm{me} \%)^{*}$} & \multirow{2}{*}{$\begin{array}{l}\text { CEC } \\
(\mathrm{me} \%)\end{array}$} & \multirow{2}{*}{$\begin{array}{l}\text { L.R.*4 } \\
(\mathrm{t} / \mathrm{ha} \\
-15 \mathrm{~cm})\end{array}$} & \multirow[b]{2}{*}{$\begin{array}{l}\text { Stones } \\
\& \\
\text { Gravel } \\
(\%)\end{array}$} & \multicolumn{5}{|c|}{ Fraction $<2,0 \mathrm{~mm}(\%)$} & \multirow{2}{*}{$\begin{array}{l}\text { Approxi- } \\
\text { mate surface } \\
\text { occupied/ } \\
\text { experiment } \\
(\%)\end{array}$} \\
\hline & & & & & & & $\mathrm{K}$ & $\mathrm{Na}$ & $\mathrm{Ca}$ & $\mathrm{Mg}$ & $\mathrm{H}$ & & & & $\begin{array}{l}\text { Coarse } \\
\mathrm{Sa}\end{array}$ & $\begin{array}{l}\text { Med. } \\
\text { Sa }\end{array}$ & $\begin{array}{l}\text { Fine } \\
\mathrm{Sa}\end{array}$ & Silt & Clay & \\
\hline \multirow{9}{*}{$\begin{array}{l}\text { Experi- } \\
\text { ment } \\
\text { I }\end{array}$} & \multirow{6}{*}{$\begin{array}{l}\text { Clovelly; } \\
\text { Southwold } \\
\text { (p. 60) } \\
\text { Clovelly; } \\
\text { Oatsdale } \\
\text { (p. 61) }\end{array}$} & $A_{1}$ & $0 / 30$ & 4,30 & 41 & 0,63 & 0,26 & 0,05 & 1,47 & 0,52 & 1,04 & 2,3 & 1,7 & 29,2 & 7,0 & 9,1 & 51,6 & 10,7 & 21,1 & \\
\hline & & $\mathrm{B}_{2,1}$ & $30 / \downarrow$ & 4,05 & 2 & 0,18 & 0,10 & 0,14 & 1,06 & 0,78 & 0,92 & 3,1 & 1,7 & 21,7 & 5,8 & 7,6 & 42,6 & 11,4 & 31,0 & 20 \\
\hline & & $A_{1}$ & $0 / 20$ & 4,20 & 28 & 0,72 & 0,29 & 0,20 & 1,39 & 0,59 & 1,50 & 2,1 & 3,2 & 21,7 & 5,5 & 7,2 & 48,4 & 14,5 & 25,6 & \multirow{4}{*}{50} \\
\hline & & $\mathrm{B}_{2,1}$ & $20 / 55$ & 3,88 & 11 & 0,28 & 0,14 & 0,18 & 0,47 & 0,24 & 2,37 & 1,7 & 6,7 & 15,8 & 5,0 & 7,0 & 45,7 & 13,0 & 28,4 & \\
\hline & & $\mathrm{B}_{2,2}$ & $55 / 90$ & 3,90 & 2 & 0,24 & 0,07 & 0,13 & 0,83 & 0,44 & 1,61 & 1,9 & 2,9 & 48,1 & 3,8 & 5,7 & 42,5 & 14,2 & 33,0 & \\
\hline & & $\mathrm{C}$ & $90 / \downarrow$ & 3,33 & 1 & 0,19 & 0,13 & 0,24 & 0,40 & 1,72 & 5,55 & 7,6 & 16,3 & 9,1 & 1,8 & 2,1 & 15,5 & 28,9 & 49,3 & \\
\hline & \multirow{3}{*}{$\begin{array}{l}\text { Clovelly; } \\
\text { Southwold } \\
\text { (p. 62) }\end{array}$} & $A_{1}$ & $0 / 30$ & 4,15 & 32 & 0,50 & 0,16 & 0,05 & 0,94 & 0,43 & 1,00 & 1,5 & 2,1 & 10,0 & 5,3 & 8,6 & 55,5 & 12,8 & 18,0 & \multirow{3}{*}{30} \\
\hline & & $\mathrm{B}_{2,1}$ & $30 / 70$ & 3,95 & 39 & 0,69 & 0,19 & 0,11 & 0,88 & 0,30 & 1,40 & 2,0 & 3,4 & 14,3 & 5,8 & 9,0 & 50,7 & 12,8 & 22,4 & \\
\hline & & $\mathrm{B}_{2,2}$ & $70 / 107$ & 4,45 & 2 & 0,10 & 0,03 & 0,03 & 0,97 & 0,30 & 0,49 & 1,4 & 0,6 & 10,5 & 3,7 & 7,6 & 53,5 & 13,8 & 21,0 & \\
\hline \multirow{12}{*}{$\begin{array}{l}\text { Experi- } \\
\text { ment } \\
\text { II }\end{array}$} & Hution; & $A_{1}$ & $0 / 40$ & 3,99 & 125 & 0,69 & 0,22 & 0,05 & 1,00 & 0,31 & 1,29 & 2,90 & 2,6 & 26,1 & 4,3 & 9,2 & 55,3 & 12,2 & 18,9 & \multirow{3}{*}{45} \\
\hline & Hutton & $\mathrm{B}_{2,1}$ & $40 / 70$ & 3,85 & 8 & 0,25 & 0,16 & 0,01 & 0,41 & 0,21 & 1,44 & 1,96 & 4,1 & 9,1 & 3,2 & 6,7 & 46,5 & 11,1 & 29,7 & \\
\hline & (p. 71) & $\mathrm{C}$ & $70 / \downarrow$ & 4,05 & 5 & 0,09 & 0,11 & 0,08 & 0,97 & 0,26 & 0,95 & 1,74 & 2,0 & 23,1 & 3,8 & 7,8 & 47,1 & 13,2 & 27,2 & \\
\hline & Clovelly: & $A_{1}$ & $0 / 30$ & 4,20 & 116 & 0,83 & 0,29 & 0,03 & 1,25 & 0,29 & 1,07 & 1,64 & 1,9 & 11,8 & 3,8 & 9,7 & 61,7 & 10,4 & 14,2 & \multirow{3}{*}{20} \\
\hline & Southwold & $\mathrm{B}_{2,1}$ & $30 / 90$ & 3,95 & 3 & 0,20 & 0,13 & 0,08 & 2,56 & 0,20 & 1,07 & 1,46 & 2,8 & 10,3 & 4,0 & 7,9 & 53,2 & 10,0 & 23,6 & \\
\hline & (p. 108) & $\mathrm{B}_{2,2}$ & $90 / \downarrow$ & 4,55 & 1 & 0,10 & 0,03 & 0,18 & 0,22 & 1,22 & 0,50 & 1,60 & 0,5 & 11,1 & 4,1 & 7,8 & 52,3 & 10,4 & 24,2 & \\
\hline & Clovelly; & $\mathrm{A}_{1}$ & $0 / 50$ & 4,65 & 37 & 0,50 & 0,29 & 0,08 & 1,53 & 0,38 & 0,64 & 1,69 & 0,5 & 33,3 & 4,6 & 8,1 & 56,7 & 9,4 & 20,8 & \multirow{3}{*}{30} \\
\hline & Southwold & $\mathrm{B}_{2,1}$ & $50 / 80$ & 4,35 & 2 & 0,20 & 0,13 & 0,08 & 0,84 & 0,38 & 0,63 & 1,48 & 0,8 & 45,2 & 3,8 & 6,0 & 50,7 & 12,1 & 25,9 & \\
\hline & (p. 104) & $B_{2,2}$ & $80 / 120$ & 4,20 & 1 & 0,20 & 0,08 & 0,14 & 0,84 & 0,41 & 0,67 & 1,86 & 1,1 & 26,5 & 3,6 & 7,0 & 47,6 & 14,7 & 27,1 & \\
\hline & Avalon; & $A_{1}$ & $0 / 40$ & 5,00 & 10 & 0,46 & 0,28 & 0,05 & 1,40 & 0,46 & 0,79 & 2,09 & 1,02 & 36,0 & 3,6 & 7,8 & 55,0 & 11,1 & 24,9 & \multirow{3}{*}{5} \\
\hline & Avalon & $\mathrm{B}_{2 \cdot 1}$ & $40 / 75$ & 5,25 & 1 & 0,20 & 0,12 & 0,10 & 1,13 & 0,73 & - & 2,38 & - & 52,7 & 3,7 & 7,4 & 51,9 & 12,1 & 26,5 & \\
\hline & (p. 124) & $\mathrm{B}_{2 \cdot 2}$ & $75 / \downarrow$ & 5,35 & 1 & 0,18 & 0,18 & 0,04 & 0,58 & 2,63 & - & 3,21 & - & 60,0 & 5,4 & 7,1 & 40,8 & 13,3 & 34,8 & \\
\hline
\end{tabular}

${ }^{* 1}$ Classification and nomenclature according to MacVicar et al., (1977). ${ }^{* 2}$ Bray N.2 extractable ${ }^{* 3}$ Ammonium chloride extractable except for $\mathrm{H}^{+}$ which was extracted with $1 \mathrm{~N} \mathrm{KCl}{ }^{* 4} \mathrm{~L} . \mathrm{R}$. = Lime Requirement according to Eksteen (1969) to attain a Ca $+\mathrm{Mg} / \mathrm{H}$ ratio of 5

number of vines measured per plot, which at this stage conformed to minimum requirements. For some unknown reason vines in Experiment I had less vigour and took longer to attain minimum requirements than those in Experiment II. The second dip in shoot growth recorded during 1977/78 in Experiment II, occurred during the season of highest rainfall and could be ascribed to the unprecedented downy mildew infection which severly damaged vineyards in the coastal region.

The effect of OM on the cumulative yield is shown in Fig. 2. Although vines on plots receiving the high applications of compost (treatment Ie), and during 1974/75 also those on plots receiving compost plus straw (treatment If), produced significantly better than the vines receiving the other OM treatments (Fig. 2a), this effect could not be demonstrated in Experiment II (Fig. 2b), in spite of the larger quantities of OM used. Soil analyses data (Table 1) show that although a considerable degree of soil variation occurred in both Experiments I and II, the soils were roughly comparable as far as classification, acidity, general chemical properties and texture (gravel being an exception) were concerned. No obvious explanation for the differences in response of vines between Experiment I and Experiment II to certain OM additions was evident.

In view of these inconsistent results concerning the effect of OM on vine performance, as well as the previous findings of Saayman \& Van Huyssteen (1980), the application of OM during soil preparation on these Hutton/ Clovelly soils remains of doubtful value, both from a technical and economical point of view. Apparently, the quantities of $\mathrm{OM}$ involved were too small when incorporated into a large volume of soil to have any convincing effect. Profile pit investigation revealed a "sandwich" effect, with the OM present in a very thin layer (Plate 1), thus not contributing to improving the physical properties of any significant soil volume. However, abundant fine roots were observed in these thin layers, and deeply placed OM may have the effect of stimulating root growth in the deeper soil layers.

The effect of depth and method of soil preparation on shoot growth, together with temperature and rainfall data are shown in Fig. 3. No significant differences between delving depths are evident (Fig. 3 (b)). During the first six years after planting vines on delve ploughed soil were significantly more vigorous than those on shallow ploughed soil, and also performed significantly better than vines on ripped soil during three seasons (Fig. 3 (c)). This higher shoot mass per hectare was directly related to both better vigour per vine and a larger number of vines per plot conforming to minimum requirements (data not shown). Concerning the effect of temperature and rainfall on shoot growth, the same pattern as for the OM treatments was found, and the same explanations are also valid in this case.

Fig. 4 shows the effect of depth and method of soil preparation on the cumulative yield of the vines. In Experiment I (Fig. 4 (a)), no differences in the yield of vines on $76 \mathrm{~cm}$ and $122 \mathrm{~cm}$ delve ploughed plots were evident. However, in Experiment II (Fig. 4 (b)) vines on delve ploughed plots produced significantly better than those on shallow ploughed plots and, during two seasons, also better than vines on ripped plots. These results are in accordance with shoot mass data (Fig. 3) and, in the case of Experiment II, also with soil depth measurements made 


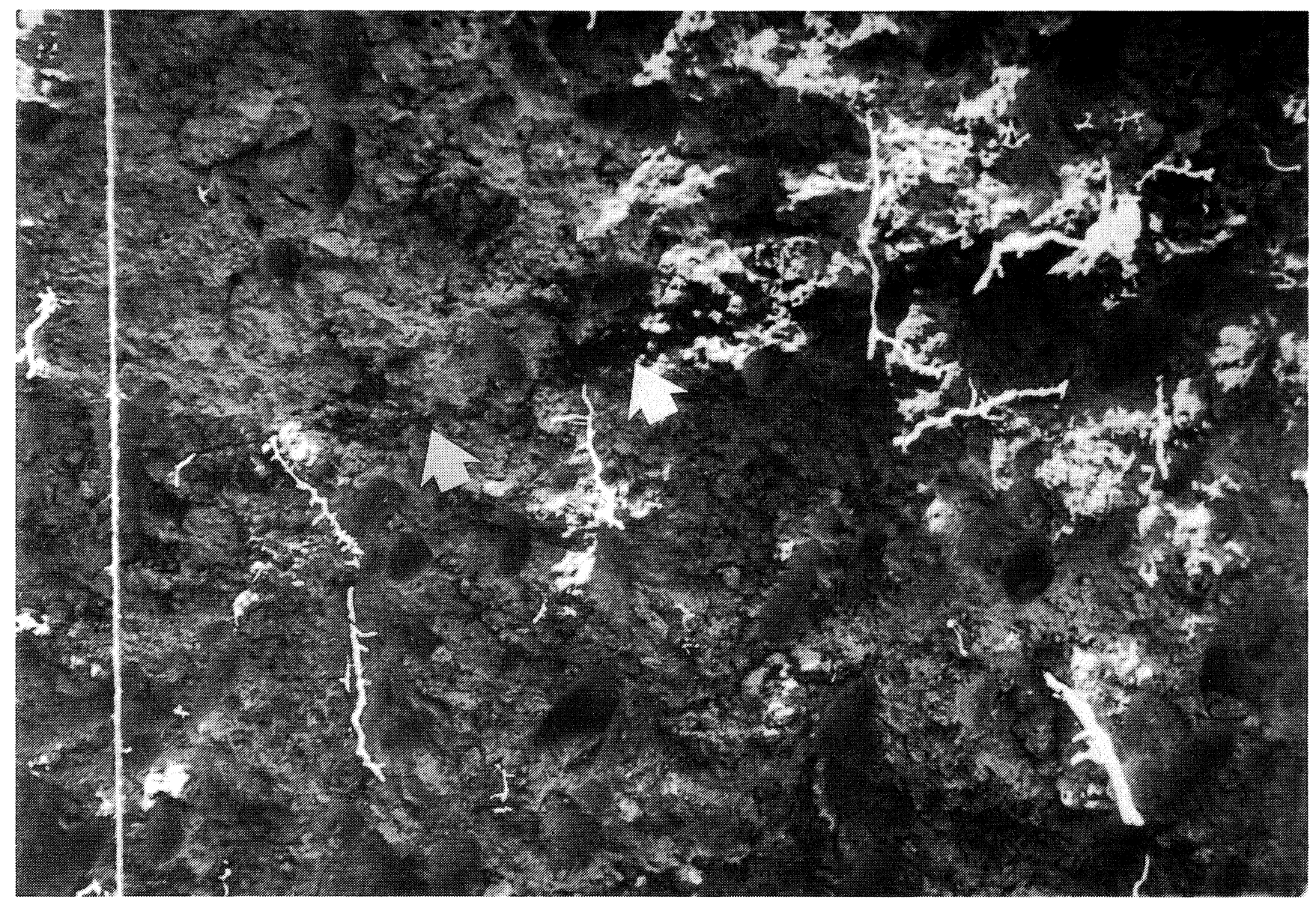

PLATE 1

Compost residue and earthworm excreta still visible as a thin dark diagonal line in a profile pit wall 14 years after applying $66 \mathrm{~m}^{3}$ compost/ha.

in profile pit walls as shown in Table 2. Shallow ploughed soil had a mean depth of $22 \mathrm{~cm}$, about $50 \%$ less than the mean depth of ripped soil, which in its turn was only half of delve ploughed soil. It was also evident that the delve plough was not able to loosen the soil to the depth of $107 \mathrm{~cm}$ originally aimed at.

TABLE 2

Mean volume and depth of Hutton/Clovelly soil loosened by different soil preparation methods

\begin{tabular}{|c|c|c|c|c|c|c|}
\hline \multirow[b]{2}{*}{$\begin{array}{l}\text { Effect } \\
\text { measured }\end{array}$} & \multicolumn{5}{|c|}{ Treatment ${ }^{1}$} & \multirow[b]{2}{*}{$\begin{array}{l}\text { Significance } \\
\text { (D-value) }\end{array}$} \\
\hline & $\mathrm{A}^{2}$ & B & $\mathrm{C}$ & $\mathrm{D}$ & $\mathrm{E}$ & \\
\hline $\begin{array}{l}\text { Volume of soil/vine } \\
\text { loosened }{ }^{3}\left(\mathrm{~m}^{3}\right)\end{array}$ & 1,02 & 1,53 & 3,25 & 3,15 & 3,36 & $* *(1,03)$ \\
\hline $\begin{array}{l}\text { Depth attained by } \\
\text { implement }{ }^{3}(\mathrm{~cm})\end{array}$ & 22 & 33 & 70 & 68 & 72 & $* *(7)$ \\
\hline
\end{tabular}

${ }^{1} \mathrm{~A}=$ shallow plough $; \mathrm{B}=$ ripper $\mathrm{C}=$ delve plough $\mathrm{D}=$ delve plough + straw; $\mathrm{E}=$ delve plough + compost

${ }^{2}$ For treatment $\mathrm{A}$, the A-horizon was measured because no disturbance of the sub-soil was evident

${ }_{3}^{3}$ Calculated from measurements made by means of a continuously recording penetrometer

*** Highly significant $(\mathrm{P} \leqslant 0,01)$

These results necessitated a check on the actual effective rooting depths created by means of delve ploughing the soil to different depths in Experiment I. Penetrometer studies (not reported here) revealed that the upper limit of undisturbed subsoil coincided with a penetrometer resistance reading of $c .50 \times 10^{2} \mathrm{kPa}\left(1,29 \mathrm{~cm}^{2} ; 30^{\circ}\right.$ small tip), which was accepted as a norm for indicating the depth of loosened soil. Using this threshold value, the mean depth of delved plots was measured by means of the penetrometer in both Experiment I and II, and the results are present in Table 3. From these data it is clear that no real differences existed in depth to which soil was loosened in the supposedly $76 \mathrm{~cm}$ and $122 \mathrm{~cm}$ delve plough depths of Experiment I. This was reflected by the lack of differences in vine performance shown in Fig. 3 (b) and Fig. 4 (a). In accordance with previous work (Saayman \& Van Huyssteen, 1980), a significant relationship between soil depth and vine performance could be demonstrated (Fig. 5). Because the best fit was obtained with linear regression, no critical soil depth was apparent, probably due to the lack of a sufficiently wide range of soil depths obtained in this study.

There is little doubt that delve ploughing similar Hutton/ Clovelly soils before planting vines, is economical, because due to this practice yield increases of $c$. $14 \mathrm{t} / \mathrm{ha}$ above shallow ploughing were already obtained during the fourth year after planting. In terms of the current minimum price for natural wine, this represents an increase in gross income of R2 702, whereas the cost of delve ploughing soil in the coastal area is currently R700 $\mathrm{R} 900 / \mathrm{ha}$, depending on the nature of the soil. However, more information concerning a critical or optimum soil depth under the prevailing climatic and soil conditions, is still lacking. The subject merits further study in order to 

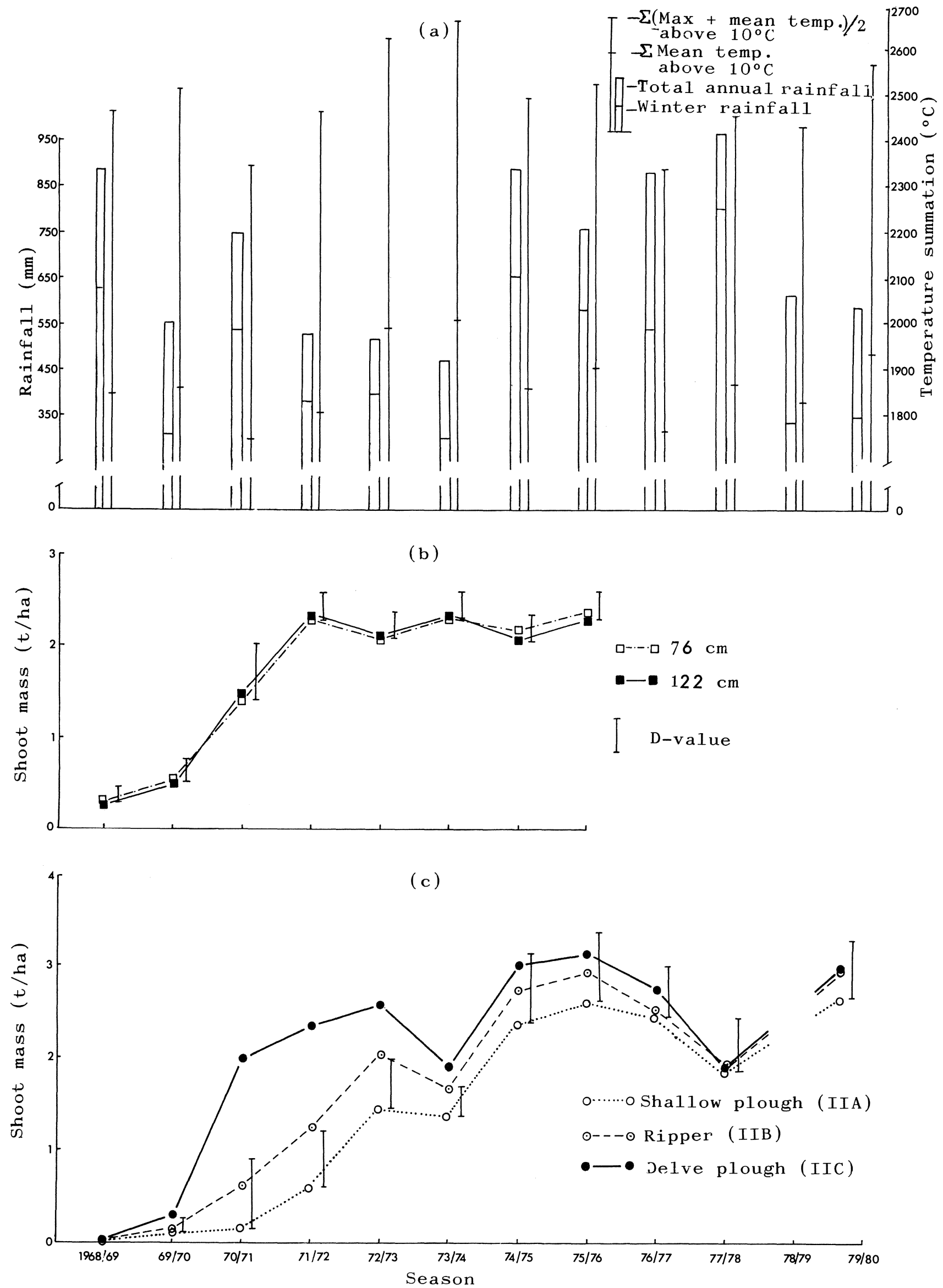

Fig. 3

The effect of (b) depth and (c) method of soil preparation on shoot mass of Colombar/143 B, Stellenbosch in relation to rainfall and temperature (a) 


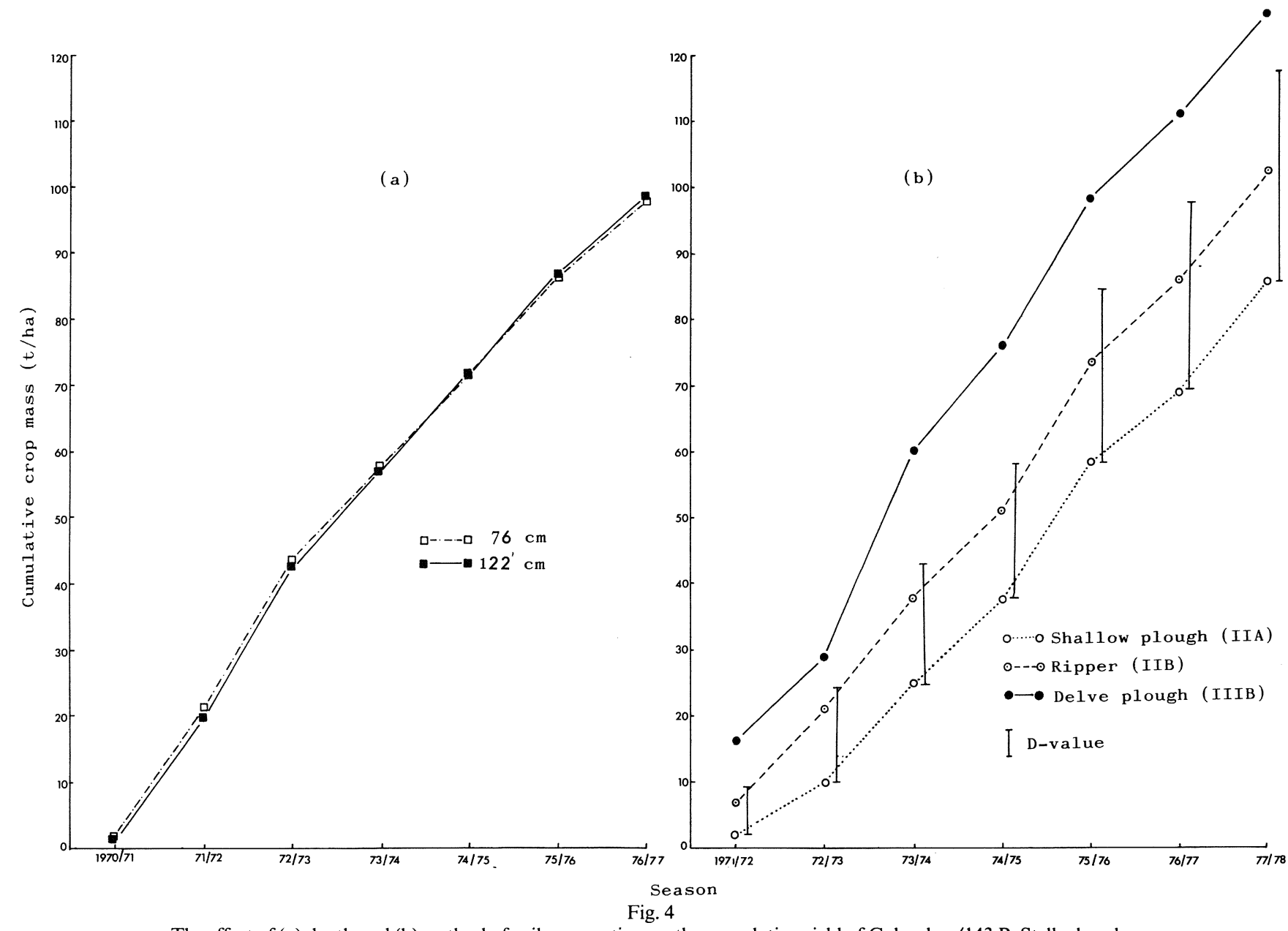

The effect of (a) depth and (b) method of soil preparation on the cumulative yield of Colombar/143 B, Stellenbosch.

facilitate decisionmaking concerning the optimum tractor size and implement to be used.

Must Composition: In Fig. 6 the effect of OM, as well as depth and method of soil preparation on must composition, is shown. (Treatment If, being very similar to treatments, Ib, c and d, was omitted for ease of interpretation.) A significant decrease in total soluble solids (TSS) and $\mathrm{pH}$, accompanied by a significant increase in total titratable acidity (TTA) of must from plots which received the highest amount of compost, as well as must from plots which received no OM (Fig. 6 (a)), was recorded during the 1974/75 season. In Experiment II only must from plots which received compost showed similar significant deviations from the other treatments during this season (Fig. 6 (b)). When considering the effect of depth and method of soil preparation, it is clear that only the shallow ploughed plots induced a comparable significant effect on TSS and $\mathrm{pH}$, the increase in TTA not being significant in this case (Fig. $6(\mathrm{~d})$ ).

These inconsistent patterns concerning treatment effects on must composition are probably related to complex interactions between production level, vine vigour and soil depth. No convincing explanations can be offered.

Soil and Roots: Water infiltration rate may be regarded as an integrated measure of various soil physical properties

TABLE 3

Mean depth of delve plough penetration in Clovelly/Hutton soil as measured by means of a penetrometer

\begin{tabular}{|c|c|c|c|c|c|c|c|c|}
\hline \multirow[t]{3}{*}{ Ploughing Depth } & \multicolumn{8}{|c|}{ Depth at which penetrometer reading exceeded $50 \mathrm{kPa} \times 10^{2 *}(\mathrm{~cm})$} \\
\hline & \multicolumn{6}{|c|}{ OM - Treatment } & \multirow[b]{2}{*}{ Mean } & \multirow[b]{2}{*}{ Significance } \\
\hline & No OM & 660 bales/ha & $\begin{array}{c}1025-1540 \\
\text { bales/ha }\end{array}$ & $34 \mathrm{~m}^{3}$ compost $/ \mathrm{ha}$ & $\begin{array}{c}50-66 \mathrm{~m}^{3} \\
\text { compost/ha }\end{array}$ & $\begin{array}{c}660 \text { bales }+ \\
34 \mathrm{~m}^{3} \text { compost } / \text { ha }\end{array}$ & & \\
\hline $76 \mathrm{~cm}$ - Experiment I & 68 & 69 & 66 & 65 & 67 & 68 & 67 & \multirow{3}{*}{ NS } \\
\hline $122 \mathrm{~cm}$ - Experiment I & 66 & 68 & 65 & 73 & 70 & 73 & 69 & \\
\hline $107 \mathrm{~cm}$ - Experiment II & 67 & - & 74 & - & 70 & - & 70 & \\
\hline Significance & & & NS & & & & 69 & \\
\hline
\end{tabular}

*A continuous recording penetrometer of $50 \mathrm{kPa} \times 10^{2}$ was found to coincide with the upper limit of undisturbed subsoil, as determined in profile pits. 


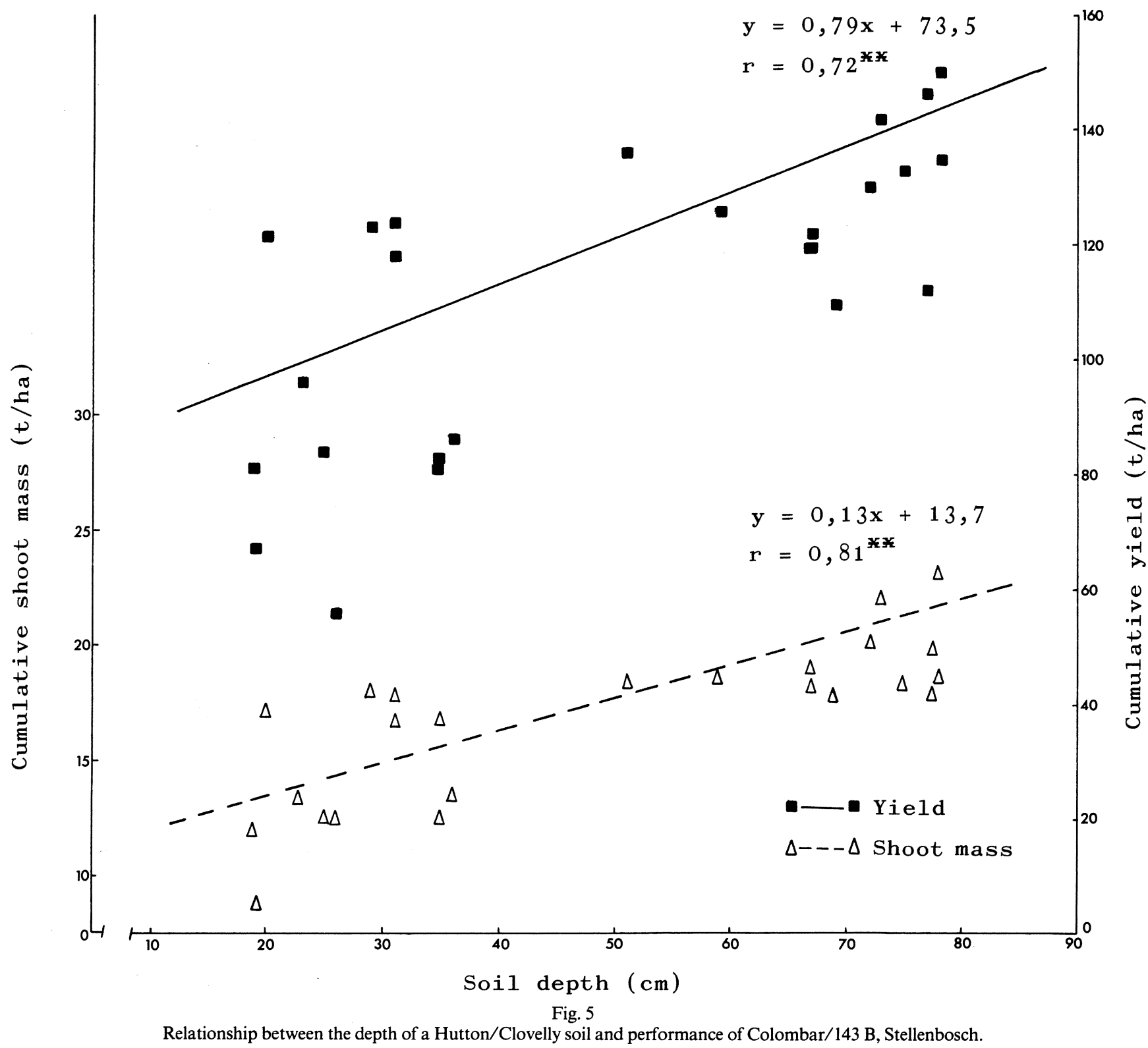

(Van Huyssteen \& Weber, 1980) and was also found to be useful in characterising differently prepared soils. The results of measurements of run-off during irrigation applied after the harvest in March 1973 in Experiment II, are shown in Fig. 7 and indicate that the delve ploughed soils tended to have better water absorbing characteristics than ripped or shallow ploughed soil. No obvious tendency concerning the effect of OM additions on water infiltration was evident. These results imply not only a better utilisation of irrigation water or rainfall in the case of deeply prepared soils compared to natural soil, but also a similar risk of erosion, an ever present potential hazard on these soils when unprotected by vegetation.

Qualitative root studies, as carried out in Experiment II in collaboration with Schulte-Karring (1977), revealed distinctive rooting patterns, shown in Plate 2 . Roots in shallow ploughed soil tended to have a general horizontal exploitation of the surface soil layers (Plate 2 (a)); roots in ripped soil clearly tended to follow the ripped zones, during which they were "trapped" at the bottom of these furrows of loosened soil (Plate 2 (b)); whereas roots in delve ploughed soil had a relatively uniform, vertically orientated distribution (Plate 2 (c)). However, the presence of huge clods of soil not broken up by the delve plough and therefore not colonised by roots, is evident from Plate 3 , and indicates that even with the latter implement the ideal soil loosening effect and root growth intensity were not attained. A second delving operation in order to achieve the desired effect is indicated but it remains to be shown whether it will be economically justifiable.

In Plate 4 photographic images of root distribution in selected representative profile pit walls are shown. The shallow and irregular depth of root distribution, roughly conforming to the loosening effect of the implement concerned, is evident in the case of shallow ploughed and ripped soils (Plate 4 (a) \& (b)), whereas a relatively uniform root distribution was obtained up to a depth of $c$. $70 \mathrm{~cm}$ in the case of delve ploughed plots (Plate 4 (c)). A 10 year old c. $100 \mathrm{~cm}$ deep profile pit was uncovered adjacent to the profile depicted in Plate 4 (a), and root distribution in this old pit was regarded as being representative of that in an ideally prepared soil (Plate 4 (d)). 

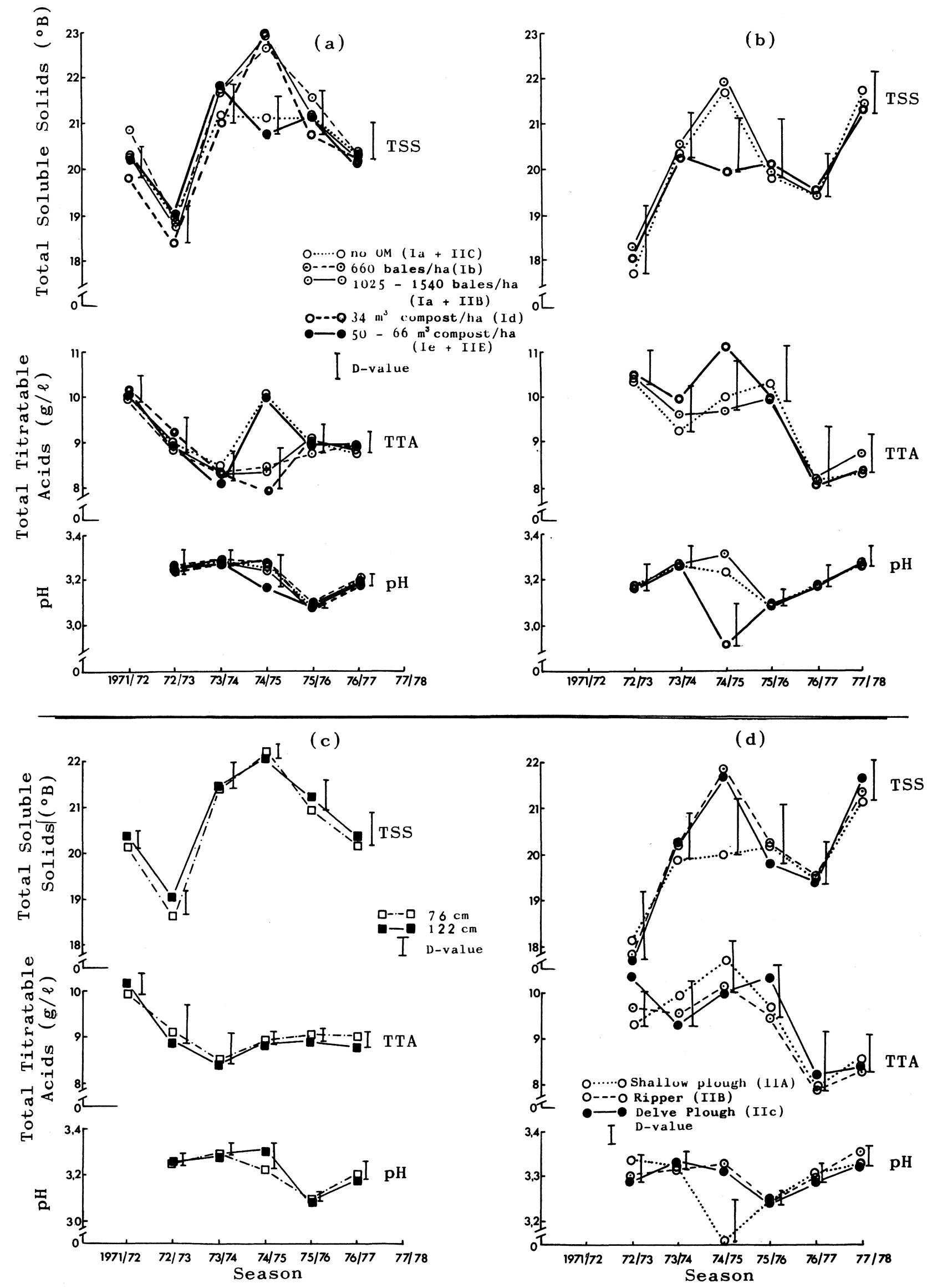

(d)

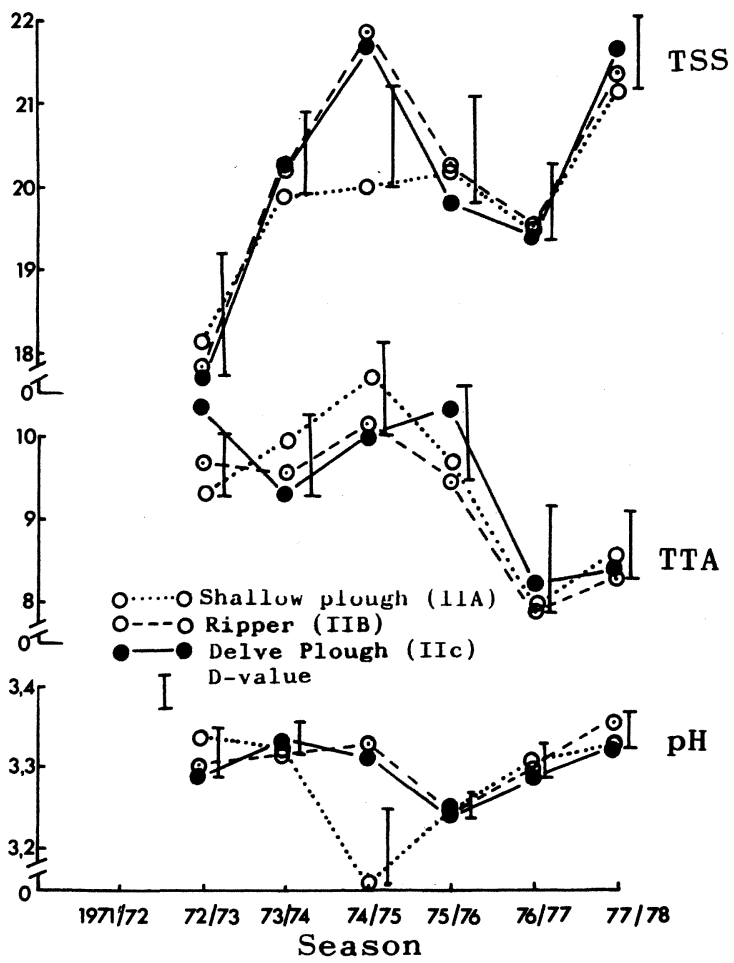

Fig. 6

Effect of organic material (a) Experiment I, (b) Experiment II; depth (c) and method (d) of soil preparation on Total Soluble Solids (TSS), Total Titratable Acids (TTA) and pH of must of Colombar/143 B, Stellenbosch. 


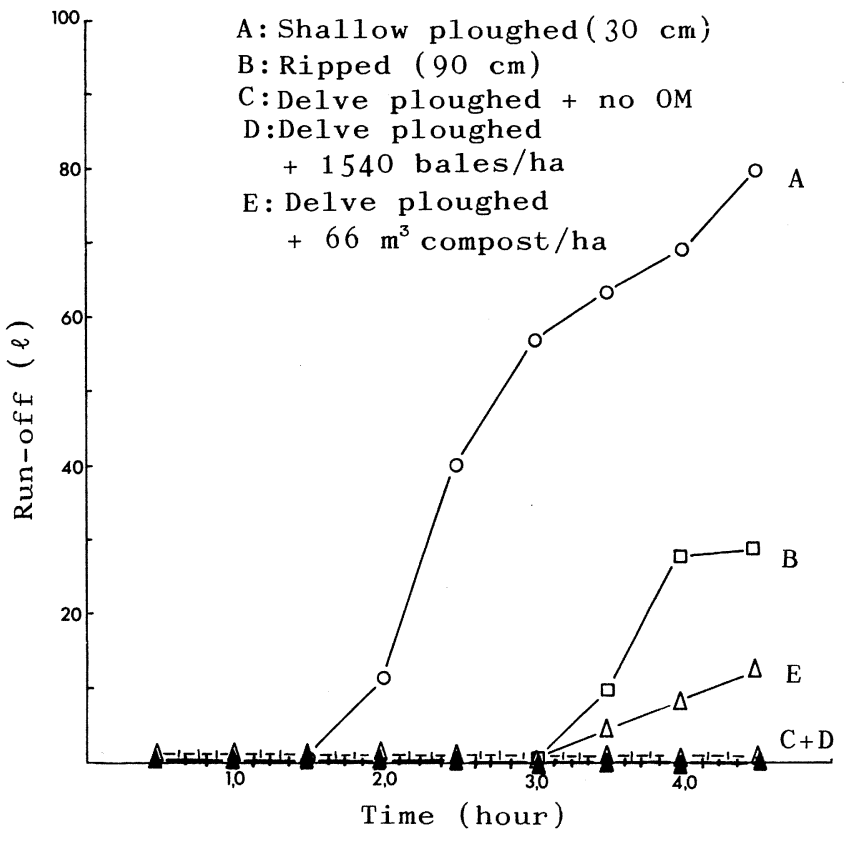

Fig. 7

Irrigation water run-off as affected by method of soil preparation and organic material additions.

Colonisation of this soil by roots occurred up to a depth of more than $100 \mathrm{~cm}$, regardless of an unfavourable subsoil pH of 3, $85-4,05$ (Table 3, Hutton soil). In accordance with shoot mass and yield data already discussed, there is no obvious general improvement in root distribution due to OM additions (Plate 4 (e) \& (f)), although localised concentrations of fine roots were evident in the thin OM layers already mentioned (Plate 1).

These qualitative findings were confirmed by actual root counts, as shown in Table 4 and Fig. 8. In comparison with delve ploughed plots, there was a significantly higher percentage of roots in the surface $0-25 \mathrm{~cm}$ layer in the case of the shallow ploughed and ripper treatments. In the case of delve ploughed plots, a significantly higher percentage of roots was present in the $50-75 \mathrm{~cm}$ soil layer (Fig. 8). Below this layer very little root growth occurred, evidently due to the shallower than expected penetration of the delve plough. Seen as a whole, shallow ploughed soil contained approximately only half the amount of roots found in delve ploughed soil, with the ripper plots occupying an intermediate position (Table 4). No clear effect of OM additions on root growth was evident but it appears as if the most homogeneous root distribution in the delved soil was obtained in soil that received no OM i.e. the addition of OM tended to enhance root growth in the deeper soil layers (Fig. 8).

By using the approach of Dupont \& Morlat (1980), the ratios of fine roots to medium plus coarse roots were also calculated but no significant effect of treatment on the intensity of root ramification could be found (data not shown). However, by calculating similar root ramification indices for roots present in an old profile pit, and those in the adjacent shallow ploughed soil (ref. Plate $4(\mathrm{~d})$ ), values of respectively 7,1 and 4,3 were obtained, indicating a positive effect of loosened soil on the root system.

The differences in rooting pattern between shallow ploughed, ripped and delve ploughed plots, explain to an important extent the differences found in shoot growth during the first few years after planting (Fig. 3 (c)). However, there is also a clear tendency for the shoot mass of vines on shallow ploughed and ripped soils to converge with that of vines on delved soil. This was probably due to single roots eventually finding a natural weakness plane in the subsoil, allowing vertical penetration and access to a greater moisture reserve. Observations in an adjacent gully next to a row of pine trees, showed the dense subsoil concerned to consist of large polygonal structural units and, therefore, having distinct weakness planes or cracks that allow occasional vertical root penetration (Plate 5). Because of the scarcity and general vertical tendency of root growth in these cracks, the roots are usually not exposed in vertical profile pit walls, thus giving the impression of a total absence of root growth in the undisturbed subsoil. These findings are in agreement with those of Branas \& Vergnes (1957) which indicated that it takes $7-8$ years for vine roots to colonise a soil, and that the ability of a rootstock in this respect is especially evident during the initial years after planting.

Nutrition: The macro-nutrient content of leaf blades and petioles sampled between bloom and véraison, is shown in Table 5. Leaf blades and petioles showed similar tendencies, and the only significant difference found was a lower $\mathrm{K}$ content of leaf blades from delved plots which received a

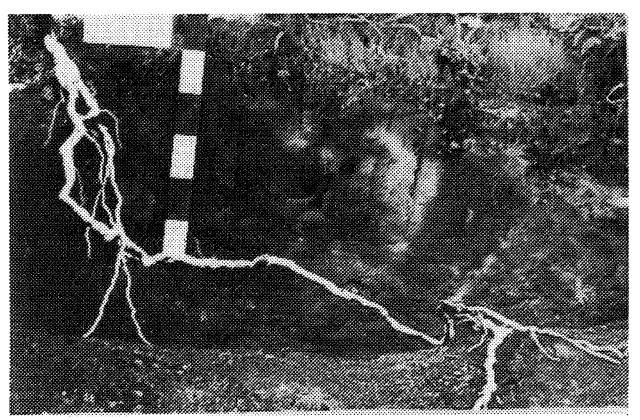

b

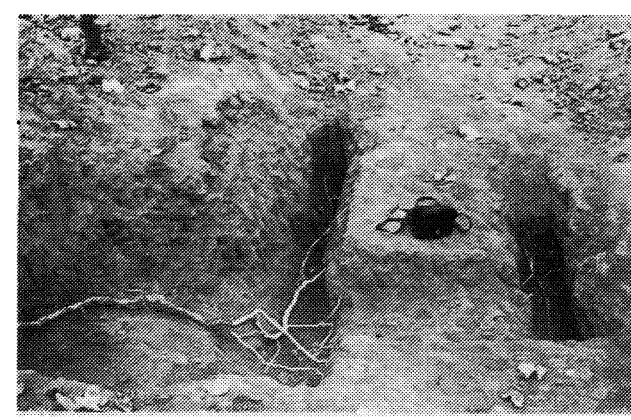

PLATE 2

General rooting pattern of Colombar/143B in (a) shallow ploughed, (b) ripped and (c) delve ploughed Hutton/Clovelly soils, Stellenbosch (Schulte-Karring, 1977). 


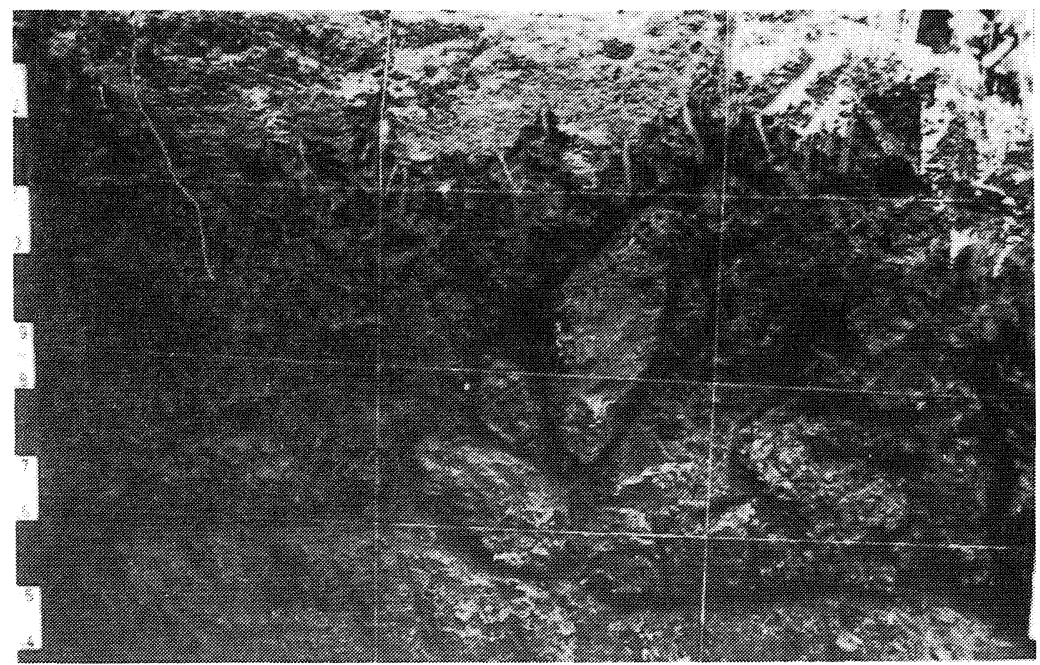

a

PLATE 3

Unbroken soil clods still present in soil solum after a delve operation (a), not being colonised by vine roots (b).

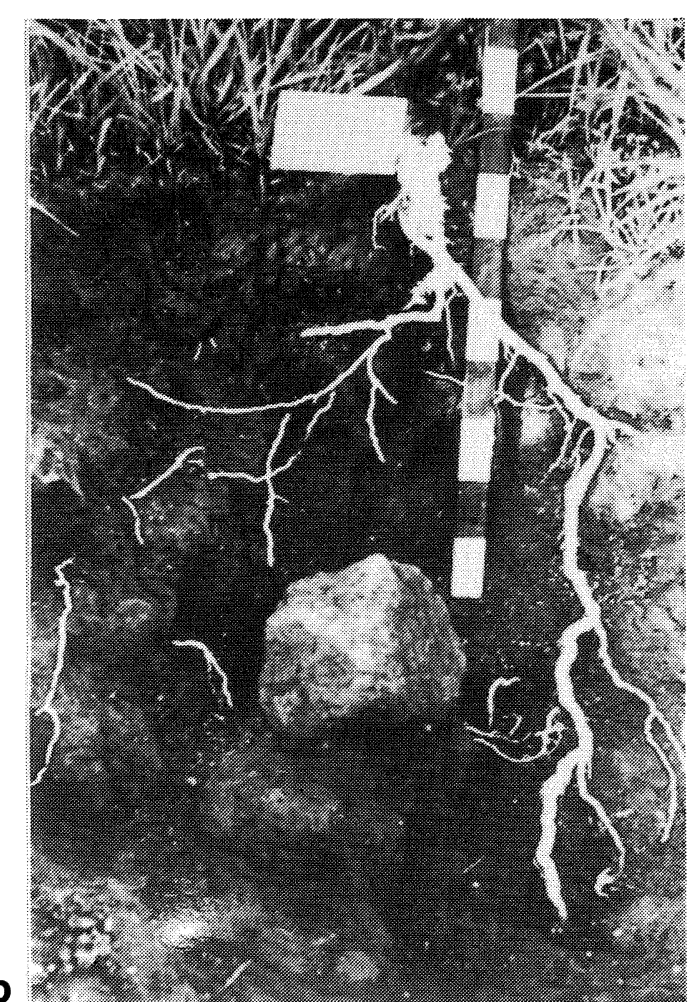

These results again emphasise the complicated problem of demonstrating direct relationships between nutrients present in the plant and those present in the soil in a field situation of varying soil physical conditions, especially in the case of a deep rooted, perennial plant like the vine (Saayman 1973). However, in general it would appear from leaf analyses that the vines were slightly deficient in straw. There is no obvious explanation for this. By using the approach of Friesen, Miller \& Juo (1980), the macronutrient content of each horizon was multiplied with the amounts of fine roots present in the horizon, and correlated with the relevant nutrient content of leaf blades and petioles but no significant relationship could be found (data not shown). b

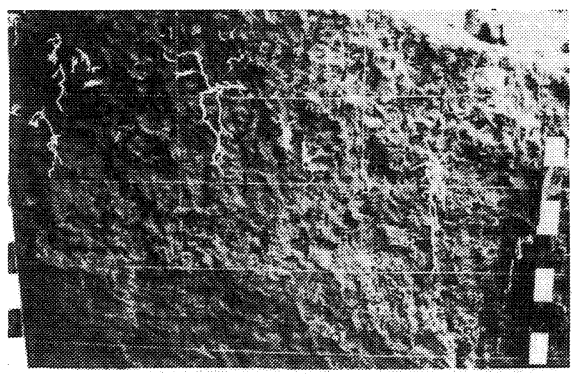

d

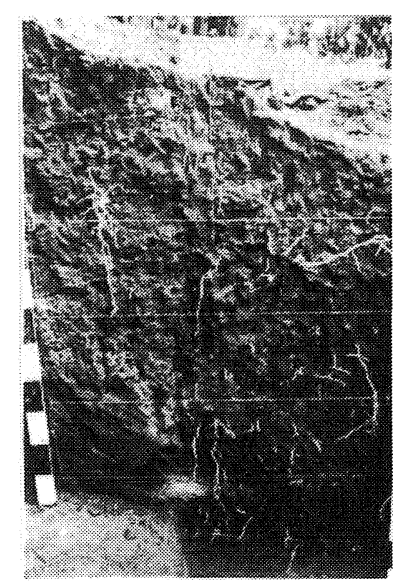

e

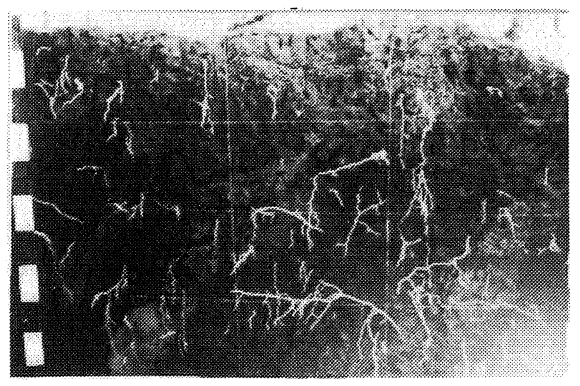

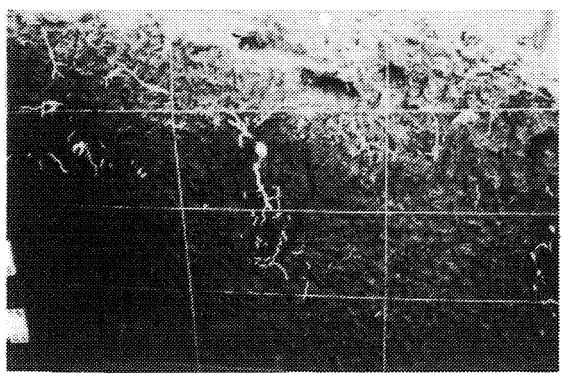

c

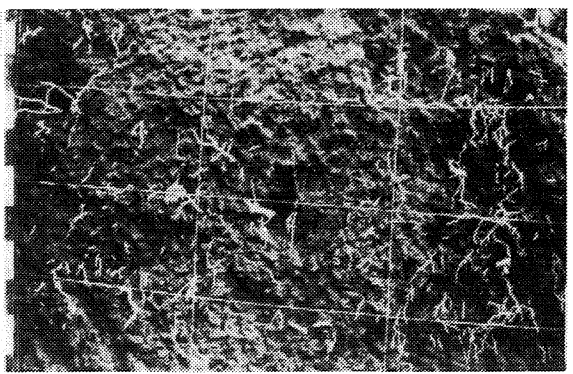

f

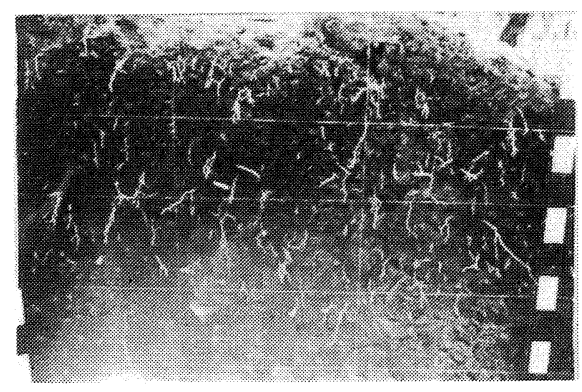

PLATE 4

Root distribution in (a) shallow ploughed; (b) ripped and (c) delve ploughed soil, (d) in an old profile pit adjacent to shallow ploughed soil and in delve ploughed plots that received (e) 1540 bales of straw/ha and (f) $66 \mathrm{~m}^{3}$ compost/ha. 


\section{Root count (\%)}

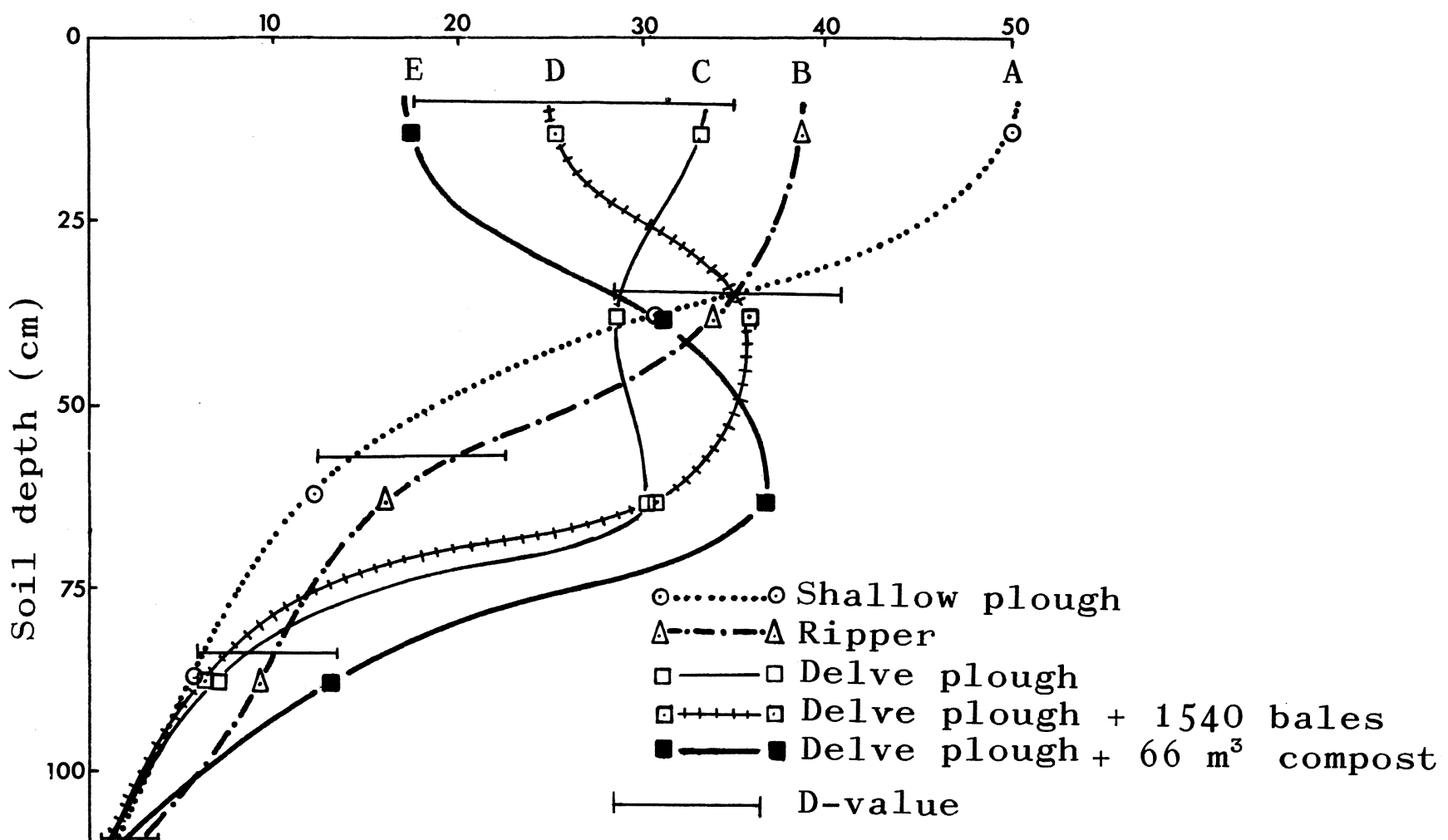

Fig. 8

Relative distribution of Colombar/143 B roots in a Hutton/Clovelly soil as affected by method of soil preparation and organic material additions.

TABLE 4

Mean distribution of roots in Hutton/Clovelly soil, Stellenbosch as affected by method of soil preparation and organic material additions.

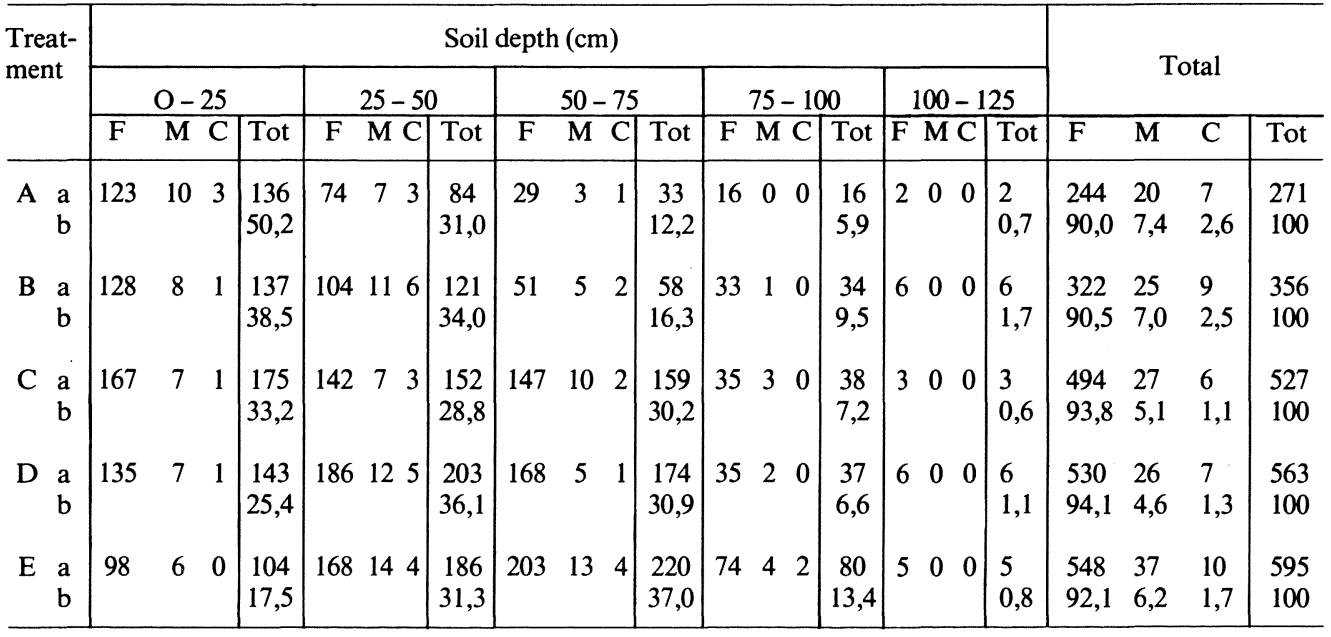

$\mathrm{A}=$ Shallow plough, $30 \mathrm{~cm}$, no $\mathrm{OM}$

$\mathrm{B}=$ Ripper, $90 \mathrm{~cm}$, no OM

$\mathrm{C}=$ Delve plough, $107 \mathrm{~cm}$, no $\mathrm{OM}$

$\mathrm{D}=$ Delve plough, $107 \mathrm{~cm},+$ straw

$\mathrm{E}=$ Delve plough, $107 \mathrm{~cm},+$ compost

$\mathrm{F}=$ Fine roots $(<2 \mathrm{~mm} \varnothing) ; \mathrm{M}=$ Medium roots $(2-7 \mathrm{~mm} \varnothing) ; \mathrm{C}=$ Coarse roots $(>7 \mathrm{~mm} \varnothing)$

$\mathrm{a}=$ amount of roots present

$\mathrm{b}=$ percentage present in horizon 
a

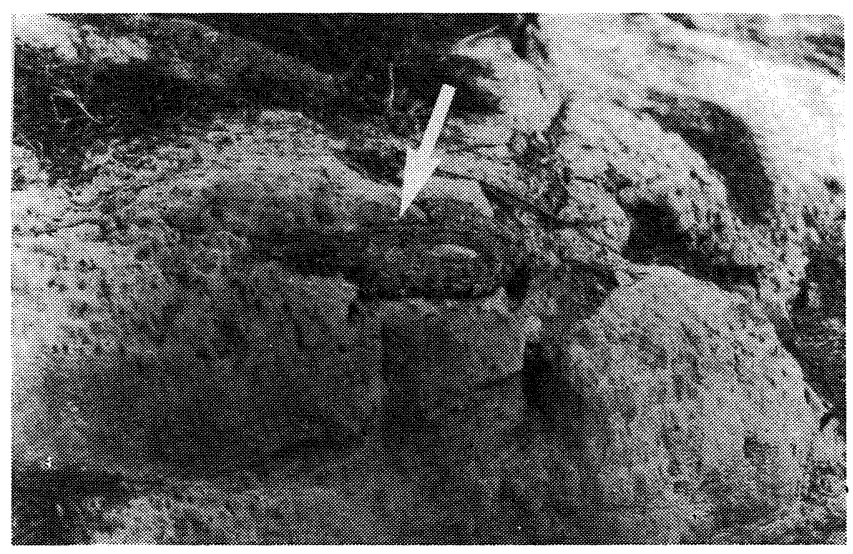

b

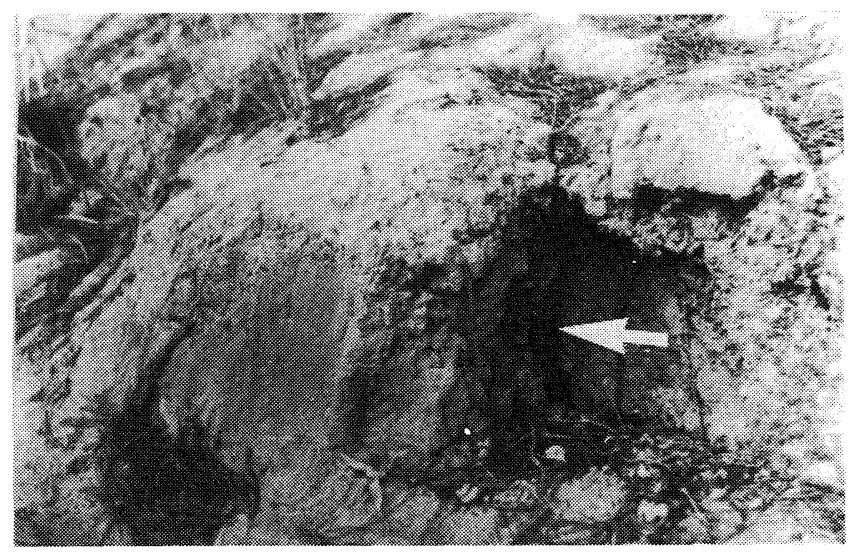

PLATE 5

Horizontal growth of pine root on contact zone between topsoil and dense subsoil of a Clovelly soil (a), with occasional roots growing vertically along weakness planes between huge polygonal structural units (b).

$\mathrm{P}$ and $\mathrm{Mg}$ (the norms of Conradie, 1981, probably being too luxurious in the case of $\mathrm{P}$ ), and markedly deficient in the case of $\mathrm{Ca}$ (Table 5). In view of the high acidity of the soil (Table 2) low $\mathrm{Ca}$ and $\mathrm{Mg}$ contents may be expected. Although a $\mathrm{P}$ content of the topsoil of more than $40 \mathrm{ppm}$ is regarded as sufficient (Saayman, 1981), the topsoil did not meet these standards in all cases, and in addition, the heavier textured subsoil was clearly deficient in $\mathrm{P}$.

Preliminary and independent work by L. van Huyssteen and W. J. Conradie of this Institute (personal communications, 1981), showed a pronounced response in both root and shoot growth of vines in pots to the application of lime on acid soils. It is, therefore, quite possible that liming the soils used for this study during soil preparation would have had a considerable additional effect on vine performance. This is an important aspect which merits urgent attention in the soils of the Cape coastal area.

\section{CONCLUSIONS}

The results of these soil preparation studies carried out in the Cape coastal region, are in accordance with similar work carried out in the vicinity of Robertson in the Breede River valley. The deep delving implements used, could only loosen the soil to a mean depth of $70-75 \mathrm{~cm}$, thus complicating one objective of this study, namely the evaluation of the effect of soil depth on vine performance.

In accordance with the findings of the Breede River investigation, no convincing effect of organic material additions could be obtained. If the addition of straw or compost during the soil preparation process did have any effect on vine performance, it was largely outweighed by the effect of soil depth and the efficiency of the soil loosening process, thus implying that the latter two aspects should in practice receive much more emphasis than the former. Because of the limited range of soil depths involved, the optimum soil depth for Hutton/Clovelly soils in the coastal region is still unknown. Ripping this type of soil is not as efficient as delve ploughing but it is clear, too, that a single delve operation is not ideal because of large clods still being present in the loosened soil. Further studies concerning the economical feasibility of a second delving operation and the optimum soil volume for vine roots under different conditions are clearly indicated. However, at this stage it is already clear that, although expensive, delve ploughing Hutton/Clovelly soils is economically feasible, because the vineyard comes into full production more rapidly, thus ensuring faster redemption of capital invested in vineyard establishment.

Colonisation of Hutton/Clovelly soils by vine roots is primarily determined by the volume of soil loosened during the soil preparation process, and there is a clear relationship between root growth and vine performance. Good soil physical conditions seem to alleviate the detrimental effects of an unfavourable soil $\mathrm{pH}$ but it is expected that correction of the latter would greatly enhance the positive effect of favourable soil physical conditions and, therefore, merits urgent further study. Concerning the effect of soil depth on root distribution pattern, it is clear that roots tend to concentrate in the surface soil layers

TABLE 5

Macro-nutrient content of Colombar/143 B leaf blades and petioles as affected by methods of soil preparation

\begin{tabular}{ll|ccccc|c|c}
\hline \multirow{2}{*}{$\begin{array}{l}\text { Element } \\
(\%)\end{array}$} & \multicolumn{5}{|c|}{ Treatment } & Significance & Norm*1 \\
\cline { 3 - 5 } (D-value) & $\mathrm{A}$ & $\mathrm{B}$ & $\mathrm{C}$ & $\mathrm{D}$ & $\mathrm{E}$ & \\
\hline $\mathrm{N}$ & $\mathrm{b}$ & 1,92 & 1,93 & 2,01 & 1,93 & 2,15 & $\mathrm{NS}$ & $1,30-1,97(2,8)$ \\
& $\mathrm{p}$ & 1,46 & 1,45 & 1,33 & 1,35 & 1,41 & $\mathrm{NS}$ & $(0,80)$ \\
\hline $\mathrm{P}$ & $\mathrm{b}$ & 0,14 & 0,14 & 0,14 & 0,14 & 0,13 & $\mathrm{NS}$ & $0,09-0,3(0,48)$ \\
& $\mathrm{p}$ & 0,08 & 0,08 & 0,09 & 0,07 & 0,11 & $\mathrm{NS}$ & $(0,63)$ \\
\hline $\mathrm{K}$ & $\mathrm{b}$ & 1,45 & 1,35 & 1,27 & 0,96 & 1,31 & $*(0,33)$ & $0,73-1,46(1,10)$ \\
& $\mathrm{p}$ & 2,76 & 2,39 & 1,82 & 1,73 & 2,13 & $\mathrm{NS}$ & $(1,9)$ \\
\hline $\mathrm{Ca}$ & $\mathrm{b}$ & 0,94 & 1,04 & 1,17 & 1,34 & 1,25 & $\mathrm{NS}$ & $1,8-2,8(1,50)$ \\
& $\mathrm{p}$ & 0,94 & 0,98 & 1,12 & 1,01 & 1,06 & $\mathrm{NS}$ & $(1,51)$ \\
\hline $\mathrm{Mg}$ & $\mathrm{b}$ & 0,17 & 0,17 & 0,17 & 0,22 & 0,14 & $\mathrm{NS}$ & $0,22-0,66(0,20)$ \\
& $\mathrm{p}$ & 0,29 & 0,31 & 0,32 & 0,37 & 0,27 & $\mathrm{NS}$ & $(0,52)$ \\
\hline $\mathrm{Na}$ & $\mathrm{b}$ & 0,05 & 0,05 & 0,05 & 0,05 & 0,06 & $\mathrm{NS}$ & 0,12 \\
& $\mathrm{p}$ & 0,09 & 0,09 & 0,09 & 0,10 & 0,11 & $\mathrm{NS}$ & - \\
\hline
\end{tabular}

$\mathrm{A}=$ shallow plough $\mathrm{B}=$ ripper $\mathrm{C}=$ delve plough, no $\mathrm{OM}, \mathrm{D}=$ delve plough plus straw; $\mathrm{E}=$ delve plough plus compost.

*1 Norms for table grapes according to Beyers (1962). Values in brackets according to Conradie (1981) as determined for Chenin blanc in sand culture.

$\mathrm{b}=$ leaf blade

$\mathrm{p}=$ petiole

NS: not significant; $*$ Significant $(P \leqslant 0,05)$ 
when soil depth is restricted, and that more uniform root distribution with depth is obtained in deeper soil, implying better buffering conditions against drought and even nutrient deficiencies. It would seem as if a loose soil induces better root ramification, and that deeply placed $\mathrm{OM}$ encourages root growth in the chemically unfavourable deeper soil layers.

Foliar analyses data indicated sub-optimum nutrition with respect to $\mathrm{P}, \mathrm{Ca}$ and $\mathrm{Mg}$, and these deficiencies could also be predicted from soil analyses. However, no relationship between either foliar analyses and soil analyses data with vine performance could be established, indicating a strong predominance of soil physical over soil chemical conditions in determining vine performance. Although no conclusive measurements were carried out, it is expected that the effect of improved soil physical conditions on vine performance would be manifested primarily through better moisture absorbing, retaining and supplying characteristics of the soil.

\section{LITERATURE CITED}

BRANAS, J. \& VERGNES, A., 1957. Morphologie du système radiculaire. Progrès agric. vitic. No. 3-4, 29 - 32; No. 7 - 8, 94 - 104; No. 9-10, 122 - 129; No. 11 - 12, 147 - 158; No. 13, 173 - 183; No. 14-15, 203 209

BEYERS, E., 1962. Diagnostic leaf analyses for deciduous fruit $S$. Afr. J. agric. Sci. 5(2), 315-329.

CONRADIE, W. J., 1981. Nutrient consumption by Chenin blanc grown in sand culture and seasonal changes in the chemical composition of leaf blades and petioles. S. Afr. J. Enol. Vitic. 2(1), $15-18$.

DUPONT, J. \& MORLAT, R., 1980. Aspects geopedologiques du vignobles de Chinon et problemes agroviticoles associes. Conn. Vigne Vin 14(1), 1-18.

EKSTEEN, L. L., 1969. The determination of the lime requirement of soils for various crops in the Winter Rainfall Region. Fert. Soc. S. Afr. J. 2, 13-14.
FRIESEN, D. K., MILLER, M. H. \& JUO, A. S. R., 1980. Liming and lime-phosphorus interactions in two Nigerian Ultisols: II Effects on maize root and shoot growth. Soil Sci. Soc. Am. J. 44, $1227-1232$.

MACVICAR, C. N. et al., 1977. Soil classification - a binomal system for South Africa. Dept. Agric. \& Fisheries, Pretoria.

MERRYWEATHER, F. R., 1965. Soils of the Wellington and Malmesbury areas. M. Sc. (Agric) Thesis, Univ. Stellenbosch, 7600 Stellenbosch.

SAAYMAN, D., 1973. Grondeienskappe en wingerdprestasie in die Bonnievale-omgewing. M. Sc. Thesis, Univ. Stellenbosch, 7600 Stellenbosch.

SAAYMAN, D., 1981. Wingerdvoeding. Wingerdbou in Suid-Afrika. 343 - 383. Eds: J. D. Burger \& J. Deist, OVRI, Stellenbosch 7600.

SAAYMAN, D \& VAN HUYSSTEEN, L., 1980. Soil preparation studies: I The effect of depth and method of soil preparation and of organic material on the performance of Vitis vinifera (var. Chenin blanc) on Hutton/Sterkspruit soil. S. Afr. J. Enol. Vitic. 1 (2), $107-121$.

SCHULTE-KARRING, H., 1977. Strukturele tekortkominge van Suid-Afrikaanse wingerdgronde en maatreëls om dit te verbeter. Wynboer No. 551, 55 62.

VAN HUYSSTEEN, L. \& WEBER, H. W., 1980. Soil moisture conservation in dryland viticulture as affected by conventional and minimum tillage practices. S. Afr. J. Enol. Vitic. 1(2), $67-75$.

WINKLER, A. J., COOK, J. A., KLIEWER, W. M. \& LIDER, L. A., 1974. General Viticulture. Univ. Calif. Press, Berkeley.

ZEEMAN, A. S., 1978. Effect of rootstocks on the performance of Chenin blanc under various environmental conditions. Proc. S. Afr. Soc. Enol. Vitic., $3-$ 4 Oct. 1978, $71-86$. 